\title{
SERUM PROLACTIN ASSAY: AN IMPORTANT SCREENING METHOD IN PRIMARY AND SECONDARY INFERTILITY IN FEMALE
}

\author{
Sanjaya Sharma1, Vidya Chaudhary², Sushila Kharakwal', Preeti Kanal ${ }^{4}$, Seema 5 , Pratima 6 , Shashi ${ }^{7}$ \\ 1 Professor and HOD, Department of Obstetrics and Gynaecology, M. L. B. Medical College, Jhansi. \\ ${ }^{2}$ Associate Professor, Department of Obstetrics and Gynaecology, M. L. B. Medical College, Jhansi. \\ ${ }^{3}$ Professor, Department of Obstetrics and Gynaecology, M. L. B. Medical College, Jhansi \\ ${ }^{4}$ Lecturer, Department of Obstetrics and Gynaecology M. L. B. Medical College, Jhansi. \\ 53rd Year Junior Resident, Department of Obstetrics and Gynaecology M. L. B. Medical College, Jhansi. \\ ${ }^{63}$ rd Year Junior Resident, Department of Obstetrics and Gynaecology M. L. B. Medical College, Jhansi. \\ 73rd Year Junior Resident, Department of Obstetrics and Gynaecology M. L. B. Medical College, Jhansi.
}

\section{ABSTRACT}

\section{BACKGROUND}

Infertility represents a common condition nowadays with important medical, economic and psychological implications. Traditionally, measurement of Prolactin has been considered an important component of infertility workup in women.

\section{AIMS}

The study was designed to evaluate the serum prolactin assay in patients with primary and secondary infertility.

\section{METHOD}

In this retrospective case control study, we investigated one fifty (150) infertile women in the age range of 20-40 years attending Department of Obs. and Gynae. MLB Medical College, Jhansi, for infertility treatment. Fifty (50) fertile women with similar age range were selected as controls. The association between infertility and levels of serum Prolactin was reviewed.

\section{RESULTS}

Hyperprolactinemia was depicted in $24.66 \%$ infertile women. Prevalence of primary infertility was $68 \%$, while that of secondary infertility cases was $32 \%$. There was a correlation between Prolactin levels in infertile subjects $(\mathrm{p}<0.05)$.

\section{CONCLUSION}

There was higher prevalence of hyperprolactinemia in infertile patients.

\section{KEYWORDS}

Prolactin (PRL), Hyperprolactinemia, Infertility.

HOW TO CITE THIS ARTICLE: Sharma S, Chaudhary V, Kharakwal S, et al. Serum prolactin assay: an important screening method in primary and secondary infertility in female. J. Evolution Med. Dent. Sci. 2016;5(16):766-768, DOI: 10.14260/jemds/2016/178

\section{INTRODUCTION}

Infertility is an important aspect of gynaecological practice. It is defined as the inability to conceive after one year of regular intercourse without contraception.(1) $30 \%$ of infertility is encountered as a result of hormonal disturbances.(2) In these hormones, prolactin plays an important role. Prolactin is a hormone secreted by the pituitary gland. The pituitary gland is also known as the hypophysis and is located just below the hypothalamus of the brain. Measurement of prolactin has been considered an important component of infertility workup in women. Hyperprolactinemia also adversely affects the fertility potential by impairing pulsatile secretion of GnRH and hence interfering with ovulation.[3] It may be seen in menstrual and ovulatory dysfunction like anovulation, amenorrhoea and galactorrhoea. ${ }^{[4]}$ Pituitary hormones such as TSH, prolactin or growth hormone may act synergistically with Follicle Stimulating Hormone (FSH) and Luteinizing Hormone (LH) to enhance the entry of non-growing follicles into growth phase.

Financial or Other, Competing Interest: None.

Submission 03-01-2016, Peer Review 07-02-2016,

Acceptance 12-02-2016, Published 24-02-2016.

Corresponding Author:

Dr. Sanjaya Sharma,

Professor and HOD,

Department of Obstetrics and Gynaecology

M. L. B. Medical College, Jhansi.

E-mail: drsanjayasharma74@gmail.com

DOI: 10.14260/jemds/2016/178
So, the aim of the study was to evaluate the serum prolactin assay in patients with primary and secondary infertility.

\section{MATERIALS AND METHODS}

This was a hospital based, retrospective case control study conducted in Outpatient Department in Obs and Gynae MLBMCH, Jhansi. The cases consisted of 150 female subjects who were suffering from infertility and were evaluated for serum prolactin assay. The inclusion criteria for the selection of cases were diagnosis of infertility (Both primary and secondary) and age between 20-40 years. The exclusion criteria that were adopted during case selection were male factor infertility and amongst female factors were tubal factor, any congenital anomaly of urogenital tract or any obvious organic lesion; 50 healthy, fertile females in similar age range were enrolled as controls. Prolactin levels of the infertile patients and controls were recorded. Prolactin levels were assayed by competitive enzyme immunoassay (ELISA) using commercially available kit. Results of prolactin were collected and recorded. The normal ranges of prolactin was 1.2$19.0 \mathrm{ng} / \mathrm{mL}$ respectively. These values were used to confirm abnormal cases.

\section{RESULTS}

Data on 150 infertile and 50 fertile women from study population were taken for analysis. Table 2 shows majority of 
cases $(49.08 \%)$ of primary infertility were in 26-30 years of age group followed by 20-25 years age group and majority of cases $(47.09 \%)$ of secondary infertility were in $26-30$ years of age group followed by $27.08 \%$ in $31-35$ years age group. Out of the total 150 infertile women, $68 \%$ were suffering from primary infertility while $32 \%$ were suffering from secondary infertility (Table 1). Table 3 shows most of the patients of primary infertility were having their married life 2-5 years followed by $6-10$ years. Table 4 shows most of secondary infirmity had period of last child birth 6-8 years followed by 35 years.

Table 5 shows level of prolactin in control group. Lower limit was $5.5 \mathrm{ng} / \mathrm{mL}$ and upper limit was $22.0 \mathrm{ng} / \mathrm{mL}$, mean level was $14.62 \mathrm{ng} / \mathrm{mL}$.

On studying serum Prolactin levels of 150 subjects, $37 \%$ had higher Prolactin levels while $63 \%$ had normal levels. Of those who had hyperprolactinemia, 26 (70.3\%) women had primary infertility and 11 (29.7\%) had secondary infertility (Table 6). The test of proportion shows high significant difference $(\mathrm{p}<0.01)$ between the two.

The mean prolactin levels in infertile patients were $21.52 \pm 17.71 \mathrm{ng} / \mathrm{mL}$ against the controls who had mean Prolactin levels of $14.62 \mathrm{ng} / \mathrm{mL}$ (normal=1.2-19ng/mL) and both groups are showing statistically significant difference to each other ( $p$ value $=0.03$ )

Incidence of galactorrhoea was 16.22 in hyperprolactinemic infertile women, which is statistically significant $(\mathrm{p}<0.01)$ Table 7.

\begin{tabular}{|c|c|c|}
\hline Cases & No. of Cases & Percentage \\
\hline a)Primary infertility & 102 & $68 \%$ \\
\hline b)Secondary infertility & 48 & $32 \%$ \\
\hline Controls & 50 & - \\
\hline Total & $\mathbf{2 0 0}$ & $\mathbf{1 0 0} \%$ \\
\hline \multicolumn{2}{|c|}{ Table 1 } \\
\hline
\end{tabular}

Table 1 shows out of the total 150 infertile women $68 \%$ were suffering from primary infertility, while $32 \%$ were suffering from secondary infertility.

\begin{tabular}{|c|c|c|c|c|c|}
\hline $\begin{array}{c}\text { Sl. } \\
\text { No. }\end{array}$ & $\begin{array}{c}\text { Age } \\
\text { Group }\end{array}$ & $\begin{array}{c}\text { Secondary } \\
\text { Infertility } \\
\text { Number }\end{array}$ & $\begin{array}{c}\text { Secondary } \\
\text { Infertility } \\
\text { \% }\end{array}$ & $\begin{array}{c}\text { Primary } \\
\text { Infertility } \\
\text { Number }\end{array}$ & $\begin{array}{c}\text { Primary } \\
\text { Infertility } \\
\%\end{array}$ \\
\hline 1 & $20-25$ & 10 & 20.80 & 42 & 41.17 \\
\hline 2 & $26-30$ & 23 & 47.90 & 50 & 49.08 \\
\hline 3 & $31-35$ & 13 & 27.08 & 10 & 9.80 \\
\hline 4 & $36-40$ & 2 & 4.22 & 0 & - \\
\hline Total & \multicolumn{5}{|c|}{ Table 2} \\
\hline \multicolumn{7}{|c|}{} & $\mathbf{4 8}$ & $\mathbf{1 0 0}$ & $\mathbf{1 0 0}$ \\
\hline
\end{tabular}

Table 2 shows majority of cases $(49.08 \%$ of primary infertility were in 26-30 years of age group followed by 20-25 years age group and majority of cases $(47.09 \%$ of secondary infertility were in 26-30 years of age group followed by $27.08 \%$ in $31-35$ years age group.

\begin{tabular}{|c|c|c|c|}
\hline Years & $2-5$ & $6-10$ & $11-15$ \\
\hline $\begin{array}{c}\text { No. of } \\
\text { patients }\end{array}$ & 80 & 17 & 5 \\
\hline \multicolumn{4}{|c|}{ Table 3 } \\
\hline
\end{tabular}

Table 3 shows correlation of years of married life in primary infertility. Most of the patients of primary infertility were having their married life 2-5 years followed by 6-10 years.

\begin{tabular}{|c|c|c|c|}
\hline No. of patients & 10 & 30 & 8 \\
\hline $\begin{array}{l}\text { Period of last child } \\
\text { birth }\end{array}$ & $3-5$ & $6-8$ & $9-11$ \\
\hline \multicolumn{4}{|c|}{ Table 4} \\
\hline
\end{tabular}

Table 4 shows correlation of secondary infertility and last child birth. Most of secondary infirmity had period of last child birth 6-8 years followed by 3-5 years.

\begin{tabular}{|c|c|c|}
\hline No. of Controls & $\begin{array}{c}\text { Range of prolactin } \\
\text { in } \mathbf{~ n g / m L}\end{array}$ & Mean+-s.d. \\
\hline 50 & $5.5-22.0$ & $14.62+-4.31$ \\
\hline \multicolumn{3}{|c|}{ Table 5 } \\
\hline
\end{tabular}

Table 5 shows level of prolactin in control group. Lower limit was $5.5 \mathrm{ng} / \mathrm{mL}$ and upper limit was $22.0 \mathrm{ng} / \mathrm{mL}$, mean level was $14.62 \mathrm{ng} / \mathrm{mL}$.

\begin{tabular}{|c|c|c|}
\hline $\begin{array}{c}\text { Infertility } \\
\text { Cases }\end{array}$ & $\begin{array}{c}\text { No. of cases with } \\
\text { hyperprolactinaemia }\end{array}$ & $\begin{array}{c}\text { \% of cases with } \\
\text { hyperprolactinaemia }\end{array}$ \\
\hline $\begin{array}{c}\text { Primary } \\
\text { infertility }\end{array}$ & 26 & 70.3 \\
\hline $\begin{array}{c}\text { Secondary } \\
\text { infertility }\end{array}$ & 11 & 29.7 \\
\hline Total & $\mathbf{3 7}$ Table 6 \\
\hline \multicolumn{3}{|c|}{} \\
\hline
\end{tabular}

Table No. 6 shows serum Prolactin levels of 150 subjects, $37 \%$ had higher Prolactin levels while $63 \%$ had normal levels. Of those who had hyperprolactinemia, 26 (70.3\%) women had primary infertility and $11(29.7 \%)$ had secondary infertility. The test of proportion shows high significant difference $(\mathrm{p}<0.01)$ between the two.

\begin{tabular}{|c|c|c|c|c|}
\hline $\begin{array}{c}\text { No. of cases with } \\
\text { hyperprolactinemia }\end{array}$ & $\begin{array}{c}\text { Cases with } \\
\text { galactorrhoea no. }\end{array}$ & $\begin{array}{c}\text { Cases with } \\
\text { galactorrhoea \% }\end{array}$ & $\begin{array}{c}\text { Cases without } \\
\text { galactorrhoea no. }\end{array}$ & $\begin{array}{c}\text { Cases without } \\
\text { galactorrhoea \% }\end{array}$ \\
\hline 37 & 6 & 16.22 & 31 & 83.78 \\
\hline $\begin{array}{c}\text { Mean serum prolactin level } \\
\text { ng/mL }\end{array}$ & 132.96 & 83.6 & \\
\hline \multicolumn{3}{|r|}{ Table 7 } \\
\hline
\end{tabular}

Table No. 7 shows the mean prolactin levels in infertile patients were $21.52 \pm 17.71 \mathrm{ng} / \mathrm{mL}$ against the controls who had mean Prolactin levels of $14.62 \mathrm{ng} / \mathrm{mL}$ (normal $=1.2$ $19 \mathrm{ng} / \mathrm{mL}$ ) and both groups are showing statistically significant difference to each other ( $p$ value $=0.03$ ). Incidence of galactorrhoea was 16.22 in hyperprolactinemic infertile women, which is statistically significant $(\mathrm{p}<0.01)$ Table 7.

\section{DISCUSSION}

Hyperprolactinemia is a common problem encountered in reproductive disorders. ${ }^{5}$ A $25 \%$ incidence has been reported. ${ }^{5}$ It is associated with oligomenorrhea, amenorrhea, anovulation, luteal phase defect and galactorrhea. 6

In our study, there were $68 \%$ women with primary infertility and $32 \%$ with secondary infertility. 
Madhuprita et al. study reported $65 \%$ incidence in primary infertility and $35 \%$ in secondary infertility. Findings of our study is approximately same as Madhuprita et al. study. ${ }^{6}$

The incidence of galactorrhea in hyperprolactinemic women was $16.22 \%$. Mishra et al. ${ }^{1}$ have reported an incidence of $20 \%$ in infertility which is approximately same as ours. The incidence of hyperprolactinemia in our study is $24.6 \%$. Mishra et al. ${ }^{7}$ have reported an incidence of $20 \%$ in infertility, which is approximately same as ours. It was $11.5 \%$ in Madhuprita et al. study. ${ }^{8}$

The mean prolactin level in hyperprolactinemic women in our study is $72.7 \mathrm{ng} / \mathrm{mL}$, whereas Mishra et al. found it to be $128.28 \pm 12.74 \mathrm{ng} / \mathrm{mL}$.

So prolactin estimation is recommended in all female patients presenting with complaints of primary and secondary infertility as treatment is possible. Dopamine agonists are the first choice treatment for both idiopathic hyperprolactinemia and for patients carrying prolactinomas. Surgery is done resistant cases. ${ }^{9}$

\section{CONCLUSION}

High serum prolactin levels are associated with menstrual disorders like amenorrhea, oligomenorrhea; ovulatory disorders like anovulation; luteal phase defect and galactorrhea. There is high prevalence of hyperprolactinemia in female patients with infertility and subfertility. So all the cases of infertility should be subjected for serum prolactin estimation. Prolactin estimation should be done at early stages of infertility checkup rather than going for more costly tests or invasive procedures. Dopamine agonists like bromocriptine, cabergoline and quinagolide administration restores normal ovarian function and is the first line treatment for most patients wishing to conceive.
Dopamine agonists are the first choice treatment for both idiopathic hyperprolactinemia and for patients carrying prolactinomas. Surgery is done on resistant cases. ${ }^{9}$

\section{REFERENCES}

1. Poppe K, Velkeniers B. Thyroid and Infertility. Vertin K Acad Geneeskd Belg 2002;64:389-99.

2. National Institute for Health and Clinical Excellence: Fertility: assessment and treatment for people with fertility problems. Nice Clinical Guideline 156, 2013.

3. Poppe K, Velkeniers B. Thyroid and Infertility. Vertin K Acad Geneeskd Belg 2002;64:389-99.

4. Topalski-Fistes N, Bujas M, et al. Hyperprolactinemia and disorders of the menstrual cycle. Med Pregl 1999 Mar-May;52(3-5):156-61.

5. Mishra R, Baveja R, Gupta V, et al. Prolactin level in infertility with menstrual irregularities. J Obstet Gynaecol India 2002;52:40-3.

6. Rutstein, Shea O, Iqbal H Shah, 2004. Infecundity, Infertility and Childlessness in Developing Countries. DHS Comparative Reports No. 9. Calverton, Maryland, USA: ORC Macro and the World Health Organization.

7. Cheung AP, et al. Advance reproductive age and fertility. J Obstet Gynaecol Can 2011;33(11):1165-75.

8. Madhuprita, et al. Prevalence of hyperprolactinemia in infertile cases and its correlation with TSH in a rural setup hospital. Int J Reprod Contracept Obstet Gynaecol 2013;2(4):626-630.

9. Melmed S, Casanueva FF, Hoffman AR, et al. Wass Clinical Practice Guideline: Diagnosis and treatment of hyperprolactinemia: an endocrine society clinical practice guideline. JCEM 96(2011), pp. 273-288. 